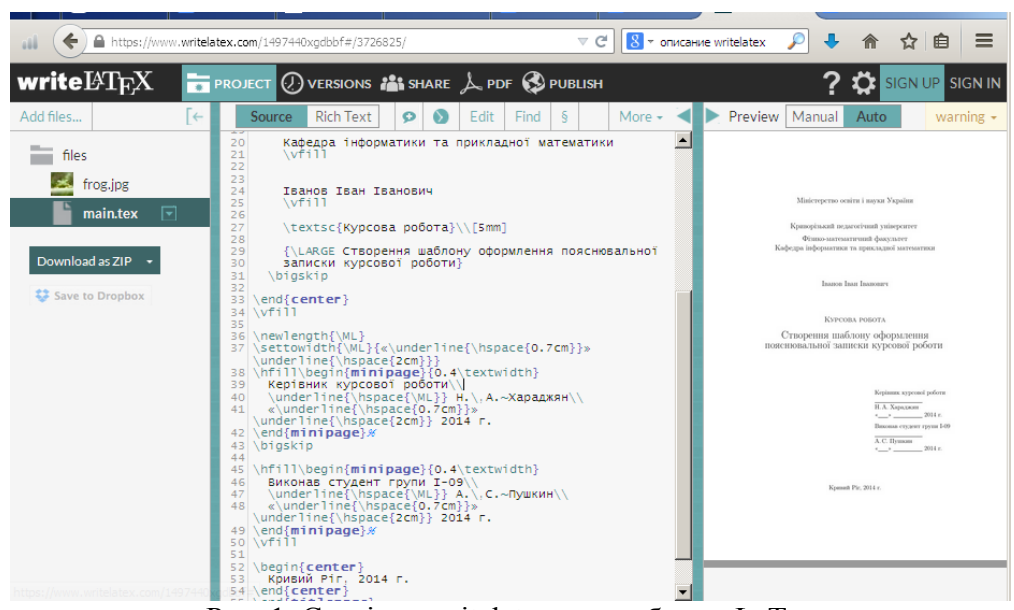

Рис. 1. Сторінка writelatex для роботи з LaTex

У статті розглянуто можливість створення шаблону оформлення пояснювальної записки курсової роботи засобами LaTeX, що відповідає вимогам, висунутим до іï оформлення. Практична значущість роботи полягає в тому, що пропонований шаблон компілюється за допомогою хмарних технологій та може в подальшому бути вдосконаленим і адаптованим для написання кваліфікаційних робіт.

\title{
Література
}

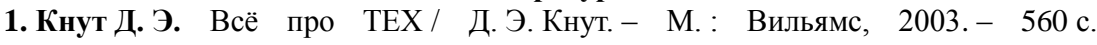
2. Положення про організацію навчального процесу у вищих навальних закладах: Наказ Міністерства освіти України № 161 від 2.06.93 р. [Електронний ресурс] // Режим доступу: http://zakon2.rada.gov.ua/laws/ show/z0071-93. 3. Про затвердження Державної програми інформатизації та комп'ютеризації вищих навчальних закладів I-II рівня акредитації на 2005-2008 роки : Постанова Кабінету Міністрів України № 1182 від 08.09.2004 р. [Електронний ресурс]// Режим доступу: http://zakon4.rada.gov.ua/laws/show/1182-2004-\%D0\%BF.

УДК 378.016: $78+159.962$

Вікторія Міщанчук

\section{ДІАГНОСТУВАННЯ РІВНІВ СФОРМОВАНОСТІ МУЗИЧНО-ВИКОНАВСЬКОЇ ПІДГОТОВКИ СТУДЕНТІВ ІНСТИТУТІВ МИСТЕЦТВ 3 ВИКОРИСТАННЯМ СУГЕСТИВНИХ ТЕХНОЛОГІЙ}

Міщанчук В. М. Діагностування рівнів сформованості музично-виконавської підготовки студентів інститутів мистецтв із використанням сугестивних технологій.

У статті розглядаються основні етапи діагностування рівнів сформованості музично-виконавської підготовки майбутніх учителів музики 3 використанням сугестивних технологій. 3'ясовано стан сформованості змістової системи використання сугестивних технологій у музично-виконавській підготовці студентів інститутів мистецтв відповідно до розроблених критеріїв і показників.

Ключові слова: майбутній учитель музики, музично-виконавська підготовка, сугестивна технологія, діагностування. 
Мищанчук В. Н. Диагностика уровней сформированности музыкальноисполнительской подготовки студентов институтов искусств с использованием суггестивных технологий.

В статье рассматриваются основные этапы диагностирования уровней сформированности музыкально-исполнительской подготовки будущих учителей музыки с использованием суггестивных технологий. Выяснено состояние сформированности содержательной системы использования суггестивных технологий в музыкально-исполнительской подготовке студентов институтов искусств в соответствии с разработанными критериями и показателями.

Ключевые слова: будущий учитель музыки, музыкально-исполнительская подготовка, суггестивная технология, диагностирование.

Mischanchuk V. N. Diagnostics of levels of formation of musical performance, training of students of institutions of art with the usage of suggestive technologies.

In the article we discuss the basic steps of diagnostics of levels of formation of musical performance, training of future music teachers with the help of suggestive technologies. The state of formation of intensional system of usage of suggestive technologies in musical performance training of students of institutions of art in compliance with developed criteria and indicators is cleared up.

Key words: future music teacher, musical performance training, suggestive technology, diagnostics.

Розбудова сучасної національної системи освіти потребує розроблення та впровадження нових підходів до музично-виконавської підготовки майбутніх учителів музики, які спрямовані на підвищення ефективності навчально-виховного процесу, творчий розвиток особистості, розкриття іiі здібностей та можливостей, саморозвиток, самовдосконалення та самореалізацію у професійній діяльності. Як зазначає О. Щолокова, розв'язання завдань фахової мистецької освіти, а саме: активізація творчого потенціалу майбутнього вчителя музики, стимулювання емоційного розвитку та художнього мислення, створення умов для широкої базової освіти та оволодіння системою поглядів для формування особистості нового типу мислення передбачає не лише вдосконалення змісту та організації навчального процесу, а й упровадження інновацій [6]. На нашу думку, такими інноваціями постають сугестивні технології, використання яких у музично-виконавській підготовці майбутніх музичних фахівців сприятиме розв'язанню завдань мистецької освіти.

Mema cmammi полягає в розкритті педагогічного діагностування 3 визначення стану сформованості музично-виконавської підготовленості майбутнього вчителя музики з використанням сугестивних технологій.

На констатувальному етапі визначення стану сформованості музичновиконавської підготовленості майбутнього вчителя музики 3 використанням сугестивних технологій брали участь 236 респондентів. Визначенням критеріальнорівневого аналізу експериментальної роботи передбачено вивчення стану сформованості означеного феномену (низький, середній та високий рівні).

Визначені рівні сформованості музично-виконавської підготовленості майбутнього вчителя музики 3 використанням сугестивних технологій мають відображати кожен зі структурних компонентів досліджуваного явища, а саме: мотиваційно-спрямований, який виражає інтерес студентів до навчання та захопленість музично-виконавською діяльністю, спрямовує їх на інтегративне 
навчання та фахове самовдосконалення; комунікативно-компетентнісний, що містить необхідну базу знань, умінь та навичок у царині оволодіння діалоговим спілкуванням, уміння адекватно оцінити набутий музично-виконавський досвід; діяльнісно-творчий, що виражає здатність до яскравого художньо-образного виконання музичних творів, уміння донести створений образ до шкільної аудиторії засобами сугестивних технік, що формують у вчителя музики не притаманні раніше художні уявлення.

Для визначення реального стану сформованості означеного явища проведено педагогічне діагностування у межах навчального процесу вищих педагогічних закладів мистецької освіти на основі визначених критеріїв музично-виконавської підготовленості майбутнього вчителя музики 3 використанням сугестивних технологій (ступінь сформованості мотиваційної спрямованості майбутніх учителів музики у процесі музично-виконавської підготовки; міра готовності майбутнього вчителя музики до діалогічного спілкування з учасниками навчального процесу; ступінь оволодіння креативно-виконавськими якостями для здійснення музичновиконавської діяльності) забезпечує визначення реального стану окресленої проблеми.

Варто зазначити, що діагностування $\epsilon$ вельми важливим етапом будь-якого педагогічного дослідження, завдяки якому відбувається розв'язання актуальних освітніх проблем мистецької освіти через фіксацію, вимірювання й оцінювання певного педагогічного явища, що дозволяє охарактеризувати стан його сформованості.

Перший етап констатувального експерименту спрямовано на визначення ступеня сформованості показників мотиваційно-спрямованого компонента музичновиконавської підготовленості майбутнього вчителя музики 3 використанням сугестивних технологій, а саме: наявності художньо-естетичної потреби до оволодіння музично-виконавськими знаннями й уміннями; виявлення інтересу до активного пізнання музичного мистецтва.

У процесі цього етапу констатувального експерименту за допомогою методів усного та письмового опитування, бесід, тестування, інтерв'ювання, спостереження за навчальною та музично-концертною діяльністю студентів музично-педагогічних факультетів та інститутів мистецтв вивчено: зацікавленість студентів музичновиконавською діяльністю; їх бажання пізнавати закони виконавської майстерності та прагнення вивчати досвід видатних виконавців; наполегливість у навчанні й спрямованість на педагогічну працю.

Так, виходячи з того, що рушійною силою розвитку особистості, спонуканням іiі до діяльності $\epsilon$ мотивація, передовсім необхідно з'ясувати місткість мотивів музичного навчання студентів. За визначенням психологів (Ю. Трофімова, П. Гончарука, В. Рибалки та ін.), мотиви не лише детермінують діяльність людини, а й пронизують більшість сфер іiі психічної активності: сприймання, мислення, уяву, пам'ять тощо [4]. Саме мотиви визначають цілеспрямовану поведінку особистості, $є$ «пусковим механізмом» (С. Сисоєва), «внутрішньою пружиною» (А. Петровський) i регулятором будь-якої діяльності. Дослідниками визнано, що мотивація пронизує всі структурні утворення особистості (спрямованість, потреби, переконання, цілі, ідеали і смаки, емоції, діяльність). Тож визначення мотивів музично-виконавської підготовленості майбутнього вчителя музики 3 використанням сугестивних технологій має важливе значення.

Спрямованість мотивів студентів на музично-виконавську підготовку, їх ставлення до музичного мистецтва визначалися під час індивідуальних бесід та 
усного опитування майбутніх учителів музики та їх педагогів. Усне опитування студентів задля виявлення їх мотивації до музично-виконавської підготовки показало, що більшість респондентів у процесі навчання в педагогічному університеті має наміри отримати передовсім музично-виконавську підготовку (63\% респондентів); частина опитаних орієнтується на музично-теоретичне навчання (28\%); при цьому мотивація навчальної діяльності менш спрямована на майбутню музично-педагогічну діяльність (25\% опитаних).

Більшої точності діагностування ставлення студентів до музично-виконавської діяльності та спрямованості на майбутню музично-педагогічну діяльність (згідно з даними вимірів за розробленими критеріями) забезпечило проведення широкого тестування майбутніх учителів музики за модифікованою відповідно до нашого дослідження методикою В. Петрушина, де респондентам пропонувалися тести на виявлення ставлення до інструментальної музично-виконавської діяльності та модифіковані тести на визначення ставлення до педагогічної діяльності [2, с. 370-374].

Результати проведеного тестування з виявлення ставлення до інструментальної музично-виконавської діяльності підтвердили попередні опитування та анкетування студентів, дали змогу зафіксувати 49\% респондентів з яскраво вираженим бажанням до музично-виконавської діяльності. Так, більшість респондентів позитивно сприйняли запитання: «Мені подобається процес концертного виконання музичних творів перед учнівською аудиторією». «На шкільних уроках під час проходження педагогічної практики мені подобається влаштовувати додаткові прослуховування музичних творів у власному виконанні» стверджувальну відповідь дали $37 \%$ опитаних. «Зазвичай я намагаюсь вивчати додатково музичні твори, окрім заданих викладачем», позитивно відповіли $32 \%$ респондентів.

Негативні відповіді («Ні») більшість студентів дала на питання: «Я вважаю, що під час концертного виконання музичного твору немає необхідності емоційно викладатися», «Виконуючи музичний твір, я зазвичай думаю про те, яке враження я справляю на слухачів», «У колі своїх друзів я рідко говорю про свій концертний виступ», «Мені буває нецікаво на більшості індивідуальних занять», «Зазвичай я забуваю зауваження педагога щодо виконання музичного твору і згадую їх в останній момент».

Тестування за модифікованою методикою В. Петрушина було проведено також задля визначення ставлення студентів до майбутньої педагогічної діяльності (відповідно до мотиваційно-спрямованого компонента).

За результатами проведеного тестування констатовано, що значна частина респондентів не має належного ставлення до музично-педагогічної діяльності (38\%). Такі студенти дали негативні відповіді на питання «Під час педпрактики у школі я сам люблю ілюструвати музичні твори учням, а не використовувати технічні засоби», «Якщо на педпрактиці у школі потрібно замінити вчителя музики, я це роблю із задоволенням», «До своєї майбутньої професії вчителя музики я ставлюся із захопленням», «Я відповідально ставлюся до будь-якого виду музично-педагогічної діяльності, особливо хвилююся під час публічних виступів перед дітьми».

Ступінь сформованості мотиваційної спрямованості майбутніх учителів музики у процесі музично-виконавської підготовки та вираження бажання студентів пізнавати закони виконавської майстерності визначалися за допомогою методів опосередкованого опитування та спостереження за навчальною діяльністю респондентів. Бесіди 3 викладачами 3 приводу виявлення студентами інститутів мистецтв пізнавальної активності на заняттях, спостереження за респондентами під 
час музичних занять та на концертних і екзаменаційних виступах забезпечили розподілення досліджуваних на три групи, що відповідали високому, середньому та низькому рівням вираження показників мотиваційно-спрямованого компонента. Згідно з визначеними вище рівнями музично-виконавської підготовленості студентів iз використанням сугестивних технологій на першому етапі констатувального експерименту нами виявлено: респондентів, яких віднесено до високого рівня музично-виконавської підготовленості $14 \%$, до середнього рівня $44 \%$. Серед досліджуваних $42 \%$ респондентів низького рівня (мотиваційно-спрямований компонент).

Діагностику комунікативно-компетентнісного компонента спрямовано на виявлення ступеня оволодіння студентами методами організації творчої взаємодії між учасниками процесу музично-виконавської діяльності (I показник) та володіння вербальними й невербальними музично-виконавськими засобами спілкування у підготовці майбутніх учителів музики (II показник). У процесі діагностування комунікативно-компетентнісного компонента важливо визначити, як майбутні вчителі музики можуть орієнтуватися в розв'язанні складних педагогічних ситуацій, пов'язаних 3 організацією творчої взаємодії між учасниками процесу музичновиконавської роботи. Задля цього у процесі фахової підготовки нами використано значну кількість завдань на підготовку студентів до розв'язання педагогічних ситуацій, спрямованих на: вибір лінії поведінки або способу виховного впливу на студента у процесі колективного музикування; вибір стратегії життя студента й деякої зміни стилю його поведінки; вибір поведінки в ситуації розв'язання конфлікту; педагогічне стимулювання; стимулювання до саморозвитку та самовиховання студента тощо.

Крім того, на семінарських заняттях студентам запропоновано розв’язати низку складних педагогічних ситуацій на витримку та виявлення ввічливості, ситуації пред'явлення вимог, вимог-принижень, ситуації довіри, переживання провини, вміння правильно вести діалог і розуміти партнера, ситуації вибору критеріїв оцінки праці викладача; ситуації досягнення успіху, самокритики й суперництва тощо.

Для встановлення ступеня фахової компетентності майбутніх учителів музики розроблено навчальні завдання, у яких використовувалась методика розв'язання студентами проблемних ситуацій (методика Р. Нємова), що дозволило визначити здатність студентів до організації творчої взаємодії з учнями на основі з'ясування проблемних ситуацій та шляхів уникнення конфліктів [1, с. 429].

У процесі діагностування критерію комунікативно-компетентнісного компонента (міри готовності майбутнього вчителя музики до діалогічної взаємодії з учасниками навчального процесу) нас цікавило володіння студентами вербальними і невербальними засобами спілкування, використання цих можливостей на уроках музики та в позакласній роботі в загальноосвітній школі, а також використання методів культурнопросвітницької діяльності майбутніми вчителями музики. Узагальнення результатів другого етапу констатувального експерименту 3 музично-виконавської підготовки студентів інститутів мистецтв та музично-педагогічних факультетів педагогічних університетів дозволило здійснити діагностування музично-педагогічної компетентності майбутніх учителів музики за модифікованою методикою О. Хоружої. 3-поміж чинників, що позитивно впливають на формування комунікативнокомпетентнісного компонента музично-виконавської підготовки, респонденти визначили такі: комунікативність учителя (54\%); інтенсивність музичновиконавського розвитку (43\%), опора на принцип співпраці у процесі гедоністичного 
навчання (64\%); наявність необхідних музично-виконавських знань, умінь та навичок (76\%). Частина респондентів (42\%) додали до попередніх позицій значущість створення сприятливого психологічного клімату з учнями, орієнтацію музичновиконавської підготовки на всебічний розвиток особистості студента.

Діагностування діяльнісно-творчого компонента спрямовано на виявлення умінь саморегуляції у процесі музично-виконавської діяльності під час сценічного виступу (І показник) та умінь до самостійної та оригінальної інтерпретації музичних творів у процесі підготовки майбутніх учителів музики (II показник) та здійснено за допомогою таких методів: опосередкованого спостереження та опитування, експертних оцінок, творчих завдань тощо. Для перевірки наявності умінь саморегуляції у студентів використано метод експертних оцінок, що поєднував опосередковане спостереження й опитування. Цей метод передбачав залучення до оцінки досліджуваного явища компетентних фахівців, що проводили спостереження та робили висновки на основі порівняльної оцінки навчальної діяльності студентів та кількісного аналізу балів, отриманих студентами на екзаменаційних виступах.

Як виявилось, середній бал респондентів на екзаменаційних виступах коливався в межах 70-89 (за 100-бальною шкалою оцінювання), що відповідало оцінці «добре». Такі оцінки віднесено до середнього рівня сформованості досліджуваного явища. Відповідно, високому відповідали 90-100 балів, а низький не перевищував 65 балів. На третьому етапі констатувального експерименту високий рівень сформованості музично-виконавської підготовленості в майбутніх учителів музики виявлено у 12\% респондентів; середній рівень становив $72 \%$; низький $-16 \%$.

Для визначення здатності студентів до створення самостійної та оригінальної виконавської інтерпретації музичного твору і ступеня вираження умінь яскравого художнього його виконання перед учнівською аудиторією запропоновано творчі завдання- самостійний вибір музичного твору для вивчення з учнями під час проходження педагогічної практики, власне виконання цього музичного твору перед учнівською аудиторією, розучування його зі школярами та самоаналіз проведеної роботи.

Зміст серії експериментальних завдань передбачав оцінювання роботи студентів щоодо вияву саморегуляції у процесі музично-виконавської діяльності та особливо під час сценічних виступів, уміння створювати самостійні та оригінальні музичні твори. Для отримання об'єктивної інформації використано тести оцінювання студентами власної музично-виконавської роботи та комплексну оцінку компетентних експертів.

Виявлення у студентів уміння прогнозувати й планувати власні педагогічні дії відповідно до змісту й розв'язання творчих завдань передбачало розроблення: орієнтирів творчого пошуку, бланків оцінювання наявності у студентів умінь саморегуляції у процесі музично-виконавської діяльності, бланки оцінних тестів тощо.

За результатами визначено рівні сформованості вищезазначених показників діяльнісно-творчого компонента, які дозволили констатувати, що на цьому етапі експериментальної роботи переважають середній та низький рівні розвитку досліджуваного явища.

Задля діагностування вмінь володіння студентами інститутів мистецтв та музично-педагогічних факультетів ВНЗ методами саморегуляції використано модифікований тест Н. Кузьміної та В. Гінецинського. Діагностування здатності до самостійного вибору студентом комплексу доцільних методів та наявність умінь самостійної та оригінальної інтерпретації музичних творів здійснювалось у процесі 
індивідуальних, практичних занять, моніторингу якості навчання, під час проведення заліків та іспитів. На практичних заняттях майбутні вчителі музики презентували власне специфічне мислення, спрямоване на вибір творчої дії для реалізації оригінальної художньої інтерпретації самостійно вивченого музичного твору.

Отже, аналіз проведеного діагностувального опитування засвідчує позитивне ставлення та інтерес респондентів до проблеми дослідження, його актуальність для студентів вищих музично-педагогічних навчальних закладів. Статистичне узагальнення здійснювалось за формулою, запропонованою С. Гончаренком для педагогічних досліджень. На основі проведених за означеною формулою обрахувань узагальнена кількість позитивних відповідей становила 69,6 \%, негативних - 19,6 \%, не визначились із відповіддю - 10,8\%.

3 огляду на зазначене вище, переважна більшість респондентів - 79,6 \% від загальної кількості опитаних - продемонструвала певні уміння щодо самостійного створення інтерпретаційної концепції музичного твору, визначила пріоритетним формування виконавської надійності засобом використання методів саморегуляції, а також підвищення рівня фахової майстерності загалом.

Отже, аналіз наведених вище результатів констатувального діагностування засвідчив перевагу середнього та низького рівнів виявлення показників музичновиконавської підготовленості майбутніх учителів музики. Понад третину респондентів віднесено до низького рівня музично-виконавської підготовленості студентів. Такі результати діагностування вимагають проведення спеціальної педагогічної роботи з використанням сугестивних технологій.

\section{Література}

1. Немов Р. С. Психология : [учеб. пособие для высш. учеб. заведений]. - В 3-х кн. - Кн. 3.: Психодиагностика: Введение в научное психологическое исследование с элементами математической статистики / Роберт Семенович Немов. - М. : ВЛАДОС, 1998. - 630, [1] c. 2. Петрушин В. И. Музыкальная психотерапия: Теория и практика : [учеб. пособие для студ. высш. учеб, заведений] / В. И. Петрушин. - М. : Гуманит. изд. центр ВЛАДОС, 2000.- 176 с. 3. Психологические тесты / под ред. А. А. Карелина : В 2-х т. - М. : ВЛАДОС, 2003. - Т. 2. 248 с. 4. Психологія : [підручник] / Ю. Л. Трофімов, В. В. Рибалка, П. А. Гончарук та ін. ; за ред. Ю. Л. Трофімова. - [4-е вид. $]$ - К. : Либідь, 2003. - 560 с. 5. Рудницька О. П. Педагогіка: загальна та мистецька : [навч. посіб.] / О. П. Рудницька. - К. : ТОВ «Інртерпроф», 2002. - 270 с. 6. Щолокова О. Мистецька освіта у контексті сучасних наукових досліджень / О. П. Щолокова / Професійно-художня освіта України : [зб. наук. праць]/ Редкол. : $\quad$ І. А. Зязюн (голова), В. О. Радкевич, Н. М. Чепурна (заступники голови) та ін. - К. : Вид-во «Черкаський ЦНТЕІ», 2007. - Вип. IV. C. $12-16$.

Іванна Размолодчикова

\section{ПЕДАГОГІЧНА ЗАДАЧА ЯК ЗАСІБ ДИДАКТИЧНОЇ ПІДГОТОВКИ МАЙБУТНІХ УЧИТЕЛІВ ПОЧАТКОВИХ КЛАСІВ}

Размолодчикова I. В. Педагогічна задача як засіб дидактичної підготовки майбутніх учителів початкових класів.

У статті подано методичні рекомендації щодо застосування педагогічних задач (ситуацій) як засобу організації навчальної і науково-дослідної роботи майбутніх 